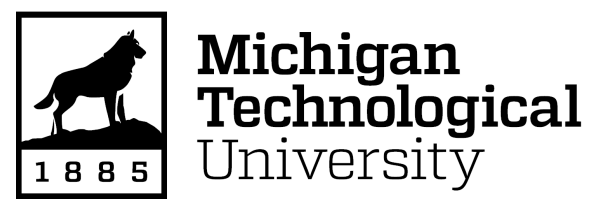

Michigan Technological University Digital Commons@Michigan Tech

\title{
Climate, wildfire, and erosion ensemble foretells more sediment in western USA watersheds
}

John B. Sankey

U.S. Geological Survey

Jason Kreitler

U.S. Geological Survey

Todd J. Hawbaker

U.S. Geological Survey

Jason L. McVay

Northern Arizona University

Mary Ellen Miller

Michigan Technological University

See next page for additional authors

Follow this and additional works at: https://digitalcommons.mtu.edu/mtri_p

Part of the Geology Commons

\section{Recommended Citation}

Sankey, J. B., Kreitler, J., Hawbaker, T. J., McVay, J. L., Miller, M. E., Mueller, E. R., Vaillant, N. M., Lowe, S. E., \& Sankey, T. T. (2017). Climate, wildfire, and erosion ensemble foretells more sediment in western USA watersheds. Geophysical Research Letters, 44(17), 8884-8892. http://dx.doi.org/10.1002/2017GL073979 Retrieved from: https://digitalcommons.mtu.edu/mtri_p/264

Follow this and additional works at: https://digitalcommons.mtu.edu/mtri_p

Part of the Geology Commons 


\section{Authors}

John B. Sankey, Jason Kreitler, Todd J. Hawbaker, Jason L. McVay, Mary Ellen Miller, Erich R. Mueller, Nicole M. Vaillant, Scott E. Lowe, and Temuulen T. Sankey 


\section{Geophysical Research Letters}

\section{RESEARCH LETTER}

10.1002/2017GL073979

\author{
Key Points: \\ - Model ensemble synthesis projects \\ $10 \%$ increase in postfire \\ sedimentation for nearly nine tenths \\ of western USA watersheds by \\ mid-21st century \\ - Postfire sedimentation projected to \\ increase by $>100 \%$ for more than one \\ third of watersheds by mid-21st \\ century \\ - Many watersheds with projected \\ increases in fire and sedimentation are \\ important surface water supply for \\ downstream human communities
}

Supporting Information:

- Supporting Information S1

Correspondence to:

J. B. Sankey,

jsankey@usgs.gov

\section{Citation:}

Sankey, J. B., J. Kreitler, T. J. Hawbaker, J. L. McVay, M. E. Miller, E. R. Mueller, N. M. Vaillant, S. E. Lowe, and

T. T. Sankey (2017), Climate, wildfire, and erosion ensemble foretells more sediment in western USA watersheds, Geophys. Res. Lett., 44, 8884-8892, doi:10.1002/2017GL073979.

Received 26 APR 2017 Accepted 4 AUG 2017 Accepted article online 7 AUG 2017 Published online 7 SEP 2017

@2017. American Geophysical Union. All Rights Reserved. This article has been contributed to by US Government employees and their work is in the public domain in the USA.

\section{Climate, wildfire, and erosion ensemble foretells more sediment in western USA watersheds}

\author{
Joel B. Sankey ${ }^{1}$ D, Jason Kreitler ${ }^{2}$ (D, Todd J. Hawbaker ${ }^{3}$ (D), Jason L. McVay ${ }^{4}$, Mary Ellen Miller ${ }^{5}$ (D), \\ Erich R. Mueller ${ }^{1}$ (D) Nicole M. Vaillant ${ }^{6}$ (D) Scott E. Lowe ${ }^{7}$ (D) and Temuulen T. Sankey ${ }^{4}$ iD \\ ${ }^{1}$ Southwest Biological Science Center, Grand Canyon Monitoring and Research Center, U.S. Geological Survey, Flagstaff, \\ Arizona, USA, ${ }^{2}$ Western Geographic Science Center, U.S. Geological Survey, Boise, Idaho, USA, ${ }^{3}$ Geosciences and \\ Environmental Change Science Center, U.S. Geological Survey, Denver, Colorado, USA, ${ }^{4}$ Informatics and Computing \\ Program, Remote Sensing and Geoinformatics Lab, Northern Arizona University, Flagstaff, Arizona, USA, ${ }^{5}$ Michigan Tech \\ Research Institute, Ann Arbor, Michigan, USA, ${ }^{6}$ U.S. Department of Agriculture Forest Service, Pacific Northwest Research \\ Station, Western Wildland Environmental Threat Assessment Center, Prineville, Oregon, USA, ${ }^{7}$ Department of Economics, \\ Boise State University, Boise, Idaho, USA
}

Abstract The area burned annually by wildfires is expected to increase worldwide due to climate change. Burned areas increase soil erosion rates within watersheds, which can increase sedimentation in downstream rivers and reservoirs. However, which watersheds will be impacted by future wildfires is largely unknown. Using an ensemble of climate, fire, and erosion models, we show that postfire sedimentation is projected to increase for nearly nine tenths of watersheds by $>10 \%$ and for more than one third of watersheds by $>100 \%$ by the 2041 to 2050 decade in the western USA. The projected increases are statistically significant for more than eight tenths of the watersheds. In the western USA, many human communities rely on water from rivers and reservoirs that originates in watersheds where sedimentation is projected to increase. Increased sedimentation could negatively impact water supply and quality for some communities, in addition to affecting stream channel stability and aquatic ecosystems.

\section{Introduction}

The area burned by wildfires worldwide is expected to increase over the next century due to climate change [Westerling et al., 2006; Gedalof et al., 2005; Littell et al., 2009; Hawbaker and Zhu, 2012a; Stephens et al., 2014; Dennison et al., 2014; Barbero et al., 2015; Pelletier et al., 2015; Robinne et al., 2016]. Increased sedimentation due to soil erosion in burned watersheds [Pierce et al., 2004; Shakesby and Doerr, 2006; Moody and Martin, 2009; Miller et al., 2011] can negatively impact downstream aquatic ecosystems and the quality and supply of water [Weidner and Todd, 2011; Murphy et al., 2015; Smith et al., 2011]. Impacts to aquatic ecosystems range from biophysical effects on fish habitat to alterations of stream channel morphology [Shakesby and Doerr, 2006; Smith et al., 2011]. Sedimentation can negatively impact water supply by reducing reservoir storage, which increases the need and cost for reservoir maintenance and the cost to treat and supply water to municipalities [Palmieri et al., 2001]. Water quality can be further degraded by nutrients and pollutants that adsorb to individual sediment grains and aggregates [Smith et al., 2011].

Fire frequency and burned area are expected to increase in many watersheds of the western USA in coming decades, particularly for the warmer climate change scenarios [Hawbaker and Zhu, 2012a; Barbero et al., 2015] (Figures $1 \mathrm{a}$ and 1b). At least $65 \%$ of the water supply in the western USA originates in watersheds with fire-prone vegetation [Brown et al., 2008]. Understanding how changing fire frequency, extent, and location will affect watersheds, reservoirs, and ecosystem services to communities is therefore of great societal importance [Weidner and Todd, 2011; MacDonald, 2010]. We use an ensemble modeling approach to examine how postfire sedimentation will change in western USA watersheds with future fire. Projections of areas burned by future wildfires for several climate change scenarios and general circulation models (GCMs) exist for all watersheds of the western USA [Hawbaker and Zhu, 2012a]. Predictions of postfire hillslope soil erosion rates also exist for many of these watersheds [Miller et al., 2011] (Figure 1c). We synthesize these data sources to project sediment yield from future fires for watersheds through the year 2050 at the hydrologic unit 8 (HUC8) scale. We demonstrate a parsimonious, ensemble model synthesis approach to project future changes in postfire watershed sediment yield that could also be applied to other regions of the world. 

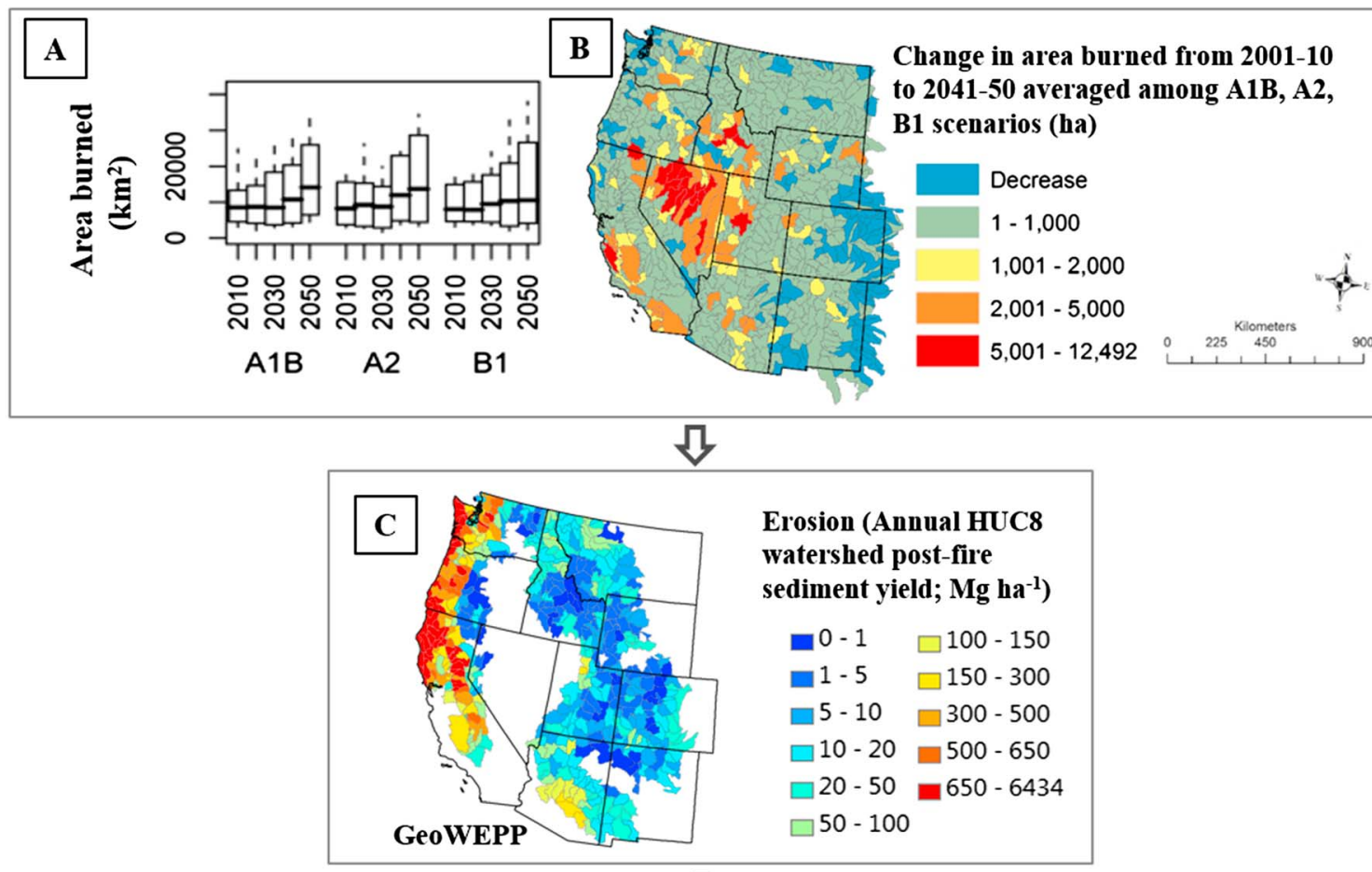

$\sqrt{5}$

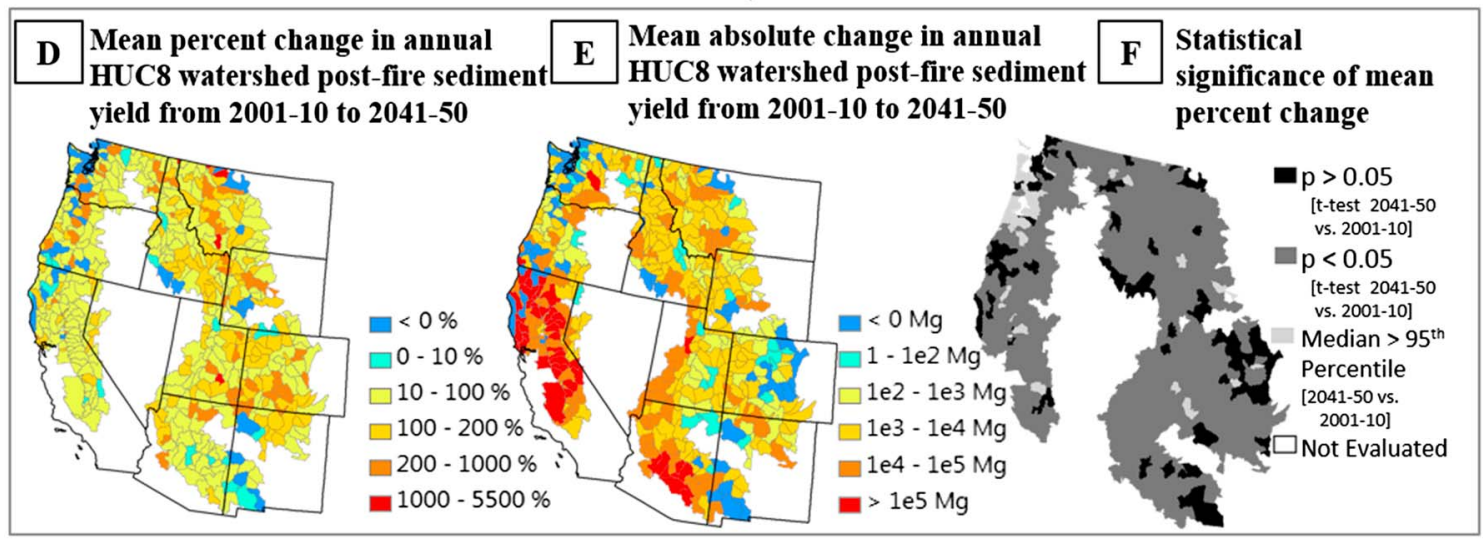

Figure 1. Overview of the data inputs and results of model ensemble projections. Previously published projections of (a) area burned from simulations of wildfire perimeters completed using climate projections from several general circulation models (GCMs) for the (b) A1B, A2, and B1 emission scenarios ([Hawbaker and Zhu, 2012a, 2012b], Figure 1a) were summarized by watershed ([Hawbaker and Zhu, 2012a, 2012b], Figure 1b), and combined with previously published watershed sediment yield estimates for the first year postfire from the (c) GeoWEPP erosion model ([Miller et al., 2011], Figure 1c) to project future postfire sediment yield for watersheds of the western USA through 2050 at the hydrological unit 8 (HUC8) scale (Figures 1d-1f; see also supporting information Figure S1). (d) The mean projected percent change in annual HUC8 watershed sediment yield from 2001-2010 to 2041-2050. (e) The projected absolute change in annual HUC8 watershed sediment $(\mathrm{Mg})$ determined from watershed area burned and first year postfire watershed sediment yield. ( $f$ ) The statistical significance of mean percent change results (i.e., in Figure 1d) from uncertainty analysis.

\section{Methods}

\subsection{Fire and Climate Change Scenarios}

We use previously published projections of future potential burned area based on simulations of wildfire ignitions and fire perimeters that were completed as part of the U.S. Geological Survey's National Assessment of Ecosystem Carbon Sequestration and Greenhouse Gas Fluxes, also known as LandCarbon [Hawbaker and Zhu, 2012a, 2012b]. For more details we refer the reader to Hawbaker and Zhu [2012a, 2012b]; however, what follows is a very brief description of their methods. 
A fire model that simulated both ignitions and fire spread was calibrated with historic data and then applied to climate projections to estimate future potential burned area [Hawbaker and Zhu, 2012a, 2012b]. The simulations stochastically modeled wildfire ignition occurrence on a daily time step and then simulated spatially explicit fire spread using the minimum travel time algorithm [Finney, 2002]. Fuel moisture, weather, climate, fuels, vegetation, and topography data were used to drive the fire simulations. The historic weather data used to parameterize and calibrate the model had $1 / 8^{\circ}$ resolution and a daily time step [Maurer et al., 2007]. The downscaled climate projections used were based on the Coupled Model Intercomparison Project phase 3 (CMIP3) climate projections following the Special Report on Emissions Scenarios (SRES). The CMIP3 data used were corrected for bias and spatially downscaled to match the $1 / 8^{\circ}$ resolution historic weather data [Maurer et al., 2007]. The downscaled data for each of the A1B, A2, and B1 SRES scenarios from the CCCma CGCM 3.1 [Flato and Boer, 2001], Australia's Commonwealth Scientific and Industrial Research Organisation Mark 3.0 model (CSIRO-Mk3.0) [Gordon et al., 2000], and the Model for Interdisciplinary Research on Climate version 3.2, medium resolution [K-1 Model Developers, 2004] general circulation models (GCMs) were downloaded from the downscaled CMIP3 and CMIP5 climate and hydrology projections archive [Maurer et al., 2007]. Before simulating fire occurrence and spread under the climate change scenarios, the ignition and fire spread components were parameterized and calibrated using Monitoring Trends in Burn Severity data [Eidenshink et al., 2007]. All model calibration and simulations were completed for individual Environmental Protection Agency Level III Ecoregions [Omernik and Griffith, 2014], and then the results were spatially joined [Hawbaker and Zhu, 2012a, 2012b].

\subsection{Postfire Sediment Modeling}

In this study, we focus on summarizing first year postfire hillslope-scale erosion due to water within HUC8 watersheds in the western USA. Soil erosion due to water depends on the spatial distribution, physical structure, and ground coverage of vegetation and litter [Flanagan and Nearing, 1995; Shakesby and Doerr, 2006; Miller et al., 2011; Larsen and MacDonald, 2007]. It also depends on soil characteristics such as texture, structure, mineralogy, aggregate stability, and organic matter content, each of which can be altered by burning and burn severity [Flanagan and Nearing, 1995; Shakesby and Doerr, 2006; Miller et al., 2011; Larsen and MacDonald, 2007]. Other important factors include rainfall amounts and intensities as well as topographic factors including slope length, steepness, shape, and convergence [Moody and Martin, 2009; Shakesby and Doerr, 2006; Miller et al., 2011]. Hillslope soil erosion is often dramatically increased by wildland fire and can be estimated for watersheds over a large geographic extent with existing geographic information system-based models including the Geo-spatial interface for the Water Erosion Prediction Project (GeoWEPP [Laflen et al., 1997; Renschler et al., 2002]) [Miller et al., 2011; Litschert et al., 2014; Sankey et al., 2015]. Modeled erosion rates can, in turn, be summarized to estimate watershed sediment yield for a given time period (e.g., 1 year) postfire [Miller et al., 2011; Sankey et al., 2015]. We use estimates of first year postfire hillslope erosion rates from GeoWEPP that were previously published for forests and shrublands in the western USA by Miller et al. [2011] (Figure 1c). We refer the reader to Miller et al. [2011] for more details; however, what follows is a brief description of the model and their methods.

Water Erosion Prediction Project (WEPP) is a complex process-based model [Miller et al., 2011] that uses key inputs of climate, topography, vegetation, soils, and land management. A spatially distributed, physically based hydrological model routes water and sediment across hillslopes and small watersheds up to the scale of several square kilometers $\left(\sim 5 \mathrm{~km}^{2}\right)$ and is driven by daily weather data that can be either created from historical measurements or generated from a stochastic weather generator [Flanagan and Nearing, 1995]. WEPP has a built-in stochastic weather generator, Cligen, which generates WEPP climate inputs from a database of over 2600 weather stations within the USA [Flanagan and Nearing, 1995]. WEPP uses the climate data to model runoff, erosion, and sediment delivery by event, month, year, or average annual values for time periods ranging from one storm to one millennia for either an individual hillslope or a watershed containing many hillslopes, channels, and impoundments [Flanagan and Nearing, 1995; Larsen and MacDonald, 2007]. WEPP calculates interrill (e.g., sheetwash) erosion, rill erosion, and erosion in small channels (i.e., ephemeral gullies) in areas of flow convergence. The WEPP model does not include landsliding, channel erosion, or debris flows. The WEPP model does not route sediment downstream in large watersheds (e.g., HUC8) but does route sediment for hillslopes and small watersheds. GeoWEPP model simulations can be run for thousands of small hillslope and watershed segments to generalize potential postfire sediment delivery to large-scale channel networks [Flanagan et al., 2013; Miller et al., 2011]. GeoWEPP develops parameterizations based on 
spatially distributed land cover type, soils, climate, and topographic data, which makes it feasible to model large areas or regions, and it allows for the use of WEPP parameter files developed by the U.S. Department of Agriculture Forest Service to represent fire disturbance which alters both the surface cover of exposed mineral soil and other factors such as rill and interill erodibility factors and effective hydraulic conductivity [Larsen and MacDonald, 2007; Elliot et al., 2006].

Miller et al. [2011] estimated postfire ground cover to parameterize GeoWEPP, using historical fire weather data and the first-order fire effects model [Miller et al., 2011]. The climate files were generated by Cligen [Nicks et al., 1995], using historical data from 739 stations to model potential first year postfire erosion in the western USA [Miller et al., 2011]. Each watershed was modeled with 5 years of stochastic weather to estimate average first year postfire erosion [Miller et al., 2011]. Miller et al. [2011] compared predicted hillslope erosion rates to validation data acquired at the hillslope plot scale and small subwatershed scale and found significant correlations for the Rocky Mountain region $\left(R^{2}=0.6\right)$.

\subsection{Projecting Future Postfire Watershed Sediment Yield}

Three replicates of wildfire burned area simulations for each climate scenario were summarized for each HUC8 watershed every year from 2001 to 2050. The annual summaries were then summarized by decade for each of the three climate scenarios. Fire severity was classified as "unburned," "low," "moderate," and "high" in the scenarios. We reclassified the burn severities to "burned" and unburned, which produced an average burned and unburned area per HUC8 watershed per decade for each climate scenario. We summarize the estimated first-year postfire erosion rate in $\mathrm{Mg} \mathrm{ha}^{-1}$ calculated from GeoWEPP by the burned area (ha) for each decade, climate scenario, and watershed to generate estimates and maps of future postfire sediment yield by decade (Figures 1 and S1 in the supporting information). Note that this model only predicts the postfire yield, and not the total sediment yield for these basins, and thus should be viewed as a change in firerelated sedimentation. For each watershed, we estimate the relative percent change in postfire sediment yield from the first to last decade of our analysis by the sediment model and the individual or combined fire/climate scenarios. When sediment yield was zero for the first decade and nonzero for the last decade, the change was assumed to be $100 \%$. When the inverse was true, the change was assumed to be $-100 \%$. When sediment yield was zero for the first and last decade, the change was assumed to be $0 \%$. In addition, for each watershed, we estimate the absolute change in postfire sediment yield from the first to last decade of our analysis by the sediment model and the individual or combined fire/climate scenarios.

\subsection{Uncertainty and Significance Analyses}

To test whether the estimated changes in postfire sediment yield were statistically significant from the first to last decade of our analysis with respect to climate and fire, we used a Monte Carlo approach to account for uncertainty in different aspects of the ensemble model associated with the sediment yield estimates. The key uncertainties considered were (1) the accuracy of the erosion modeling, (2) the assumption that future erosion response to fire will be equal to that of the recent past, (3) that projected effects of burn severity were not explicitly incorporated into the ensemble modeling, and (4) that climate and specifically rainfall effects for soil erosion may not be stationary through the five-decade time frame of our projections.

In the Monte Carlo analysis, we focused on the 471 watersheds with GeoWEPP model estimates of postfire erosion [Miller et al., 2011] and the first (2001-2010) and last (2041-2050) decades of the study period. In the first step of the analysis, for each watershed we generated 1000 realizations of annual postfire sediment yield $\left(\mathrm{Mg} \mathrm{ha}^{-1}\right)$ from a normal distribution with the mean equal to the model predicted sediment yield (i.e., Figure 1c) and error terms from the independent validation of the erosion model and from the effect of nonstationarity of climate (rainfall) on erosion estimates. The first error term was a root-mean-square error (RMSE) we estimated from a validation of model estimates [Miller et al., 2011] compared to published observations of postfire sediment yield in Moody and Martin [2009]. The RMSE value we estimated and used was $179 \mathrm{Mg} / \mathrm{ha} / \mathrm{yr}$, which represents a conservative (e.g., large relative to estimates in Figure 1c) estimate of the average error associated with model estimates of postfire erosion. The second error term was derived from sensitivity analyses published in Miller et al. [2011] for the effects of climate variability on modeled postfire erosion for the wettest (i.e., greatest uncertainty) climate region of the western USA. The second error term value, $141 \mathrm{Mg} / \mathrm{ha} / \mathrm{yr}$, is the standard deviation of modeled postfire erosion for the LandFire Zone 3 [Miller et al., 2011], which is also large relative to estimates in Figure 1c. The second error term value is an 


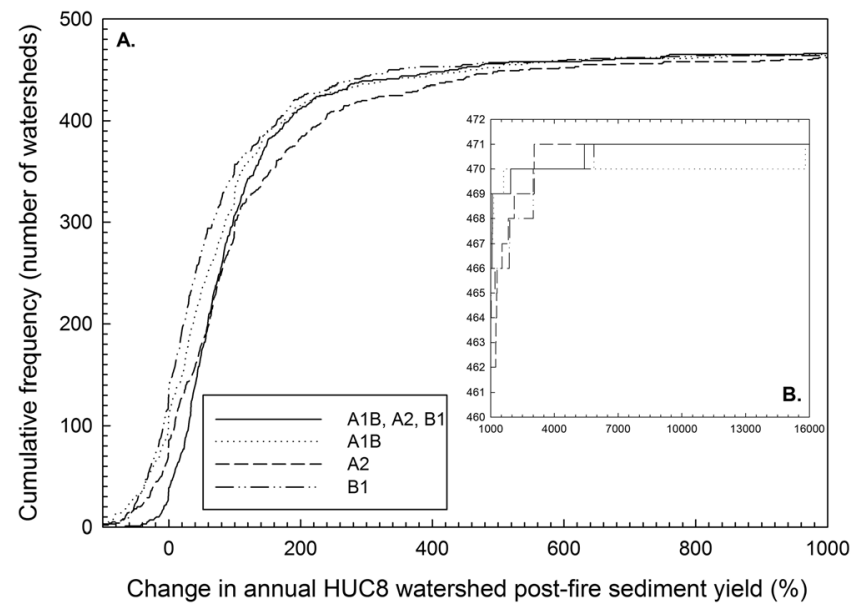

Figure 2. (a) Cumulative frequency of percent change in annual postfire sediment yield for the 471 HUC8 watersheds for the different climate and fire scenarios. (b) The tail of the distribution for postfire sediment yields greater than $1000 \%$. Note the different $x$ and $y$ axis scales in Figures $2 \mathrm{a}$ and $2 \mathrm{~b}$. estimate of the possible error associated with modeled erosion estimates if the climate were, for example, to dramatically shift (e.g., into or out of drought) during the time frame of our projections. Realizations in this and later steps with negative values were interpreted to equal zero.

The second step of the uncertainty analysis explicitly incorporated uncertainty associated with potential effects of variability in burn severity. We generated 1000 realizations of projected burned area per watershed, climate model scenario, and decade from a normal distribution with mean and standard deviation of the burned area per watershed, climate scenario, and decade for each of the three severity classes of low, moderate, and high.

In the third step of the uncertainty analysis, we multiplied each respective realization of postfire erosion and burned area (i.e., from uncertainty analysis steps 1 and 2, respectively) to generate 1000 realizations of postfire sediment yield per erosion model and climate/fire scenario combination within each watershed and decade. The third step of the uncertainty analysis resulted in a total of 3000 realizations of postfire sediment yield per watershed and decade.

Lastly, we generated a final set of 1000 estimates of postfire sediment per watershed and decade using a normal distribution and the mean and standard deviation of the 3000 realizations from step 3 . We then used a one-tailed $t$ test to test the hypothesis that postfire sediment in the decade 2041-2050 is significantly greater than in the decade 2001-2010 for each watershed. We also compared the median of the projected sediment yield in 2041-2050 to the 95th percentile of the projected sediment yield in 2001-2010 to assess for each watershed whether a projected increase in postfire sediment in the decade 2041-2050 is particularly robust and certain with respect to the range of climate and wildfire during the decade 2001-2010.

\section{Results and Discussion}

\subsection{Projected Changes in Postfire Sedimentation}

Eighty-eight percent of watersheds in the western USA are projected by the ensemble to undergo $>10 \%$ increases in sediment yield between 2001 and 2050 due to increases in burning and postfire hillslope soil erosion (Figures $1 \mathrm{~d}$ and 2). Thirty-five percent of watersheds are projected to undergo $>100 \%$ increases in sediment yield, and $1 \%$ of watersheds are projected to have $>1000 \%$ increases in sediment yield, during the same time span (Figures 1d and 2). The increases in sediment yield are driven by projected climate change-induced increases in wildfire ignitions (up to 74\%) and area burned (up to 95\%) through 2050 [Hawbaker and Zhu, 2012a] (Figures 1a and 1b). Projected absolute changes in postfire sediment yields due to changes in area burned range from $-7 \times 10^{5}$ to $2 \times 10^{6} \mathrm{Mg}$ per watershed between 2001 and 2050 (Figure 1e).

We find that 388 of the 471 watersheds are projected to have a significant increase in postfire sediment yield by the decade 2041-2050 based on a one-sided $t$ test comparison (watersheds identified as " $p<0.05$ ( $t$ test 2041-2050 versus 2001-2010)" in Figure 1f). Moreover, there are 37 watersheds where the median of projected sediment yield by 2041-2050 exceeds the 95th percentile of the projected sediment yield at the beginning of the century, and thus, the projected increase is particularly robust and certain with respect to the range of natural variability (watersheds identified as "median > 95th percentile (2041-2050 versus 2001-2010)" in Figure 1f). 


\subsection{Fire and Climate Change Scenarios}

Burned area and sediment yield are projected to increase in the western USA across the three climate scenarios considered, though more so for the warmer A1B and A2 scenarios [Hawbaker and Zhu, 2012a] (Figures 1a and 2; see also supporting information Figure S1). The projected increases in burned area are likely realistic because the scenarios and GCMs on which they are based are representative of past climate patterns and the range of temperature and precipitation extremes in the western USA [Hawbaker and Zhu, 2012a]. Burned area projections have not yet been produced (i.e., as in Hawbaker and Zhu [2012a]) for newer scenarios and climate projections of the fifth assessment report (AR5) of the Intergovernmental Panel on Climate Change. However, the differences are not large between the CMIP3 and CMIP phase 5 (CMIP5) climate projections when multiple scenarios are used, and the warming predicted among the $A 1 B, A 2$, and $B 1$ scenarios of the SRES and CMIP3 is within the range predicted by newer climate projections [Rogelj et al., 2012]. Therefore, the projected increases in burned area and sediment yield might be conservative.

\subsection{Future Postfire Sediment Modeling and Comparisons}

There is a relatively limited number of models available for predicting postfire erosion and important processes thereof. The GeoWEPP modeling approach differs from other postfire sediment models [e.g., Gabet and Dunne, 2003; Istanbulluoglu et al., 2004] that focus on slope-dependent soil creep and gully and landslide processes. Those models, however, do not include rill and interrill erosion, which can be important postfire erosion processes on many hillsides [Moody and Martin, 2001]. The ephemeral gully component of the WEPP model is analogous to the gully erosion component of other models [e.g., Istanbulluoglu et al., 2003, 2004], in that it is a slope-driven effective shear stress approach that allows for erosion and channel widening in the context of downslope sediment continuity [Flanagan and Nearing, 1995]. The WEPP model does not include landsliding, channel erosion, or debris flows, however, and those types of stochastic events certainly contribute to postfire sediment yields in many environments. WEPP also does not simulate fluvial sediment transport processes that dominate at very large drainage areas. Many detailed studies using other modeling approaches [Gabet, 2003; Gabet and Dunne, 2003; Istanbulluoglu et al., 2002, 2003, 2004; Lancaster et al., 2003] have been completed in basins of size 2 to $3 \mathrm{~km}^{2}$, which is approximately the size of the largest watersheds that can be modeled within GeoWEPP. However, a utility of GeoWEPP is that model simulations can be run for thousands of small hillslope and watershed segments to generalize potential postfire sediment delivery to large-scale channel networks. While other models may have more detailed parameterizations for individual subwatersheds [e.g., Gabet, 2003; Gabet and Dunne, 2003; Istanbulluoglu et al., 2002, 2003, 2004; Lancaster et al., 2003], GeoWEPP develops parameterizations based on spatially distributed land cover type, soils, climate, and topographic data. Thus, GeoWEPP allowed us to complete data synthesis over very large areas, such as the forested lands of the western USA.

One way to evaluate the GeoWEPP estimates of postfire sediment yield from hillslope erosion is to consider them along a continuum of measured sediment yields available for unburned watersheds and for debris flows and landslides in burned watersheds. For watersheds of similar geographic region and size, estimates of sediment yield due to postfire hillslope erosion should be greater than background sediment yields measured with gaging and trapping in unburned conditions, because burning increases soil erosion [Shakesby and Doerr, 2006; Moody and Martin, 2009; Miller et al., 2011]. However, they should be smaller than sediment yields measured from postfire debris flows and landslides, because while those mass wasting events occur less frequently compared to hillslope erosion events (e.g., recurrences on the order of $10^{2}-10^{3}$ years compared to $10^{\circ}-10^{2}$ years, respectively), they can produce very large sediment yields over small watershed areas [Meyer and Pierce, 2003; Pierce et al., 2004]. Figure 3 compares the postfire sediment estimates used in this study [Miller et al., 2011] with measurements from the Idaho Batholith, where numerous erosion rate and sediment yield data exist [Clayton and Megahan, 1986; Istanbulluoglu et al., 2004; Kirchner et al., 2001; Mueller and Pitlick, 2013; Mueller et al., 2016; Meyer et al., 2001; Meyer and Pierce, 2003] and also for coastal Northern California (as an additional example) [Andrews and Antweiler, 2012; Willis and Griggs, 2003; Gartner et al., 2004]. In the Idaho Batholith, GeoWEPP estimates of watershed sediment yield from postfire hillslope erosion are generally greater than unburned watershed sediment yields measured with gaging and sediment trapping, consistent with the expectation that postfire erosion should be greater than background sediment yields [Clayton and Megahan, 1986; Kirchner et al., 2001; Mueller and Pitlick, 2013]. Erosion rates from cosmogenic radionuclides [Kirchner et al., 2001], which reflect average erosion rates that are 


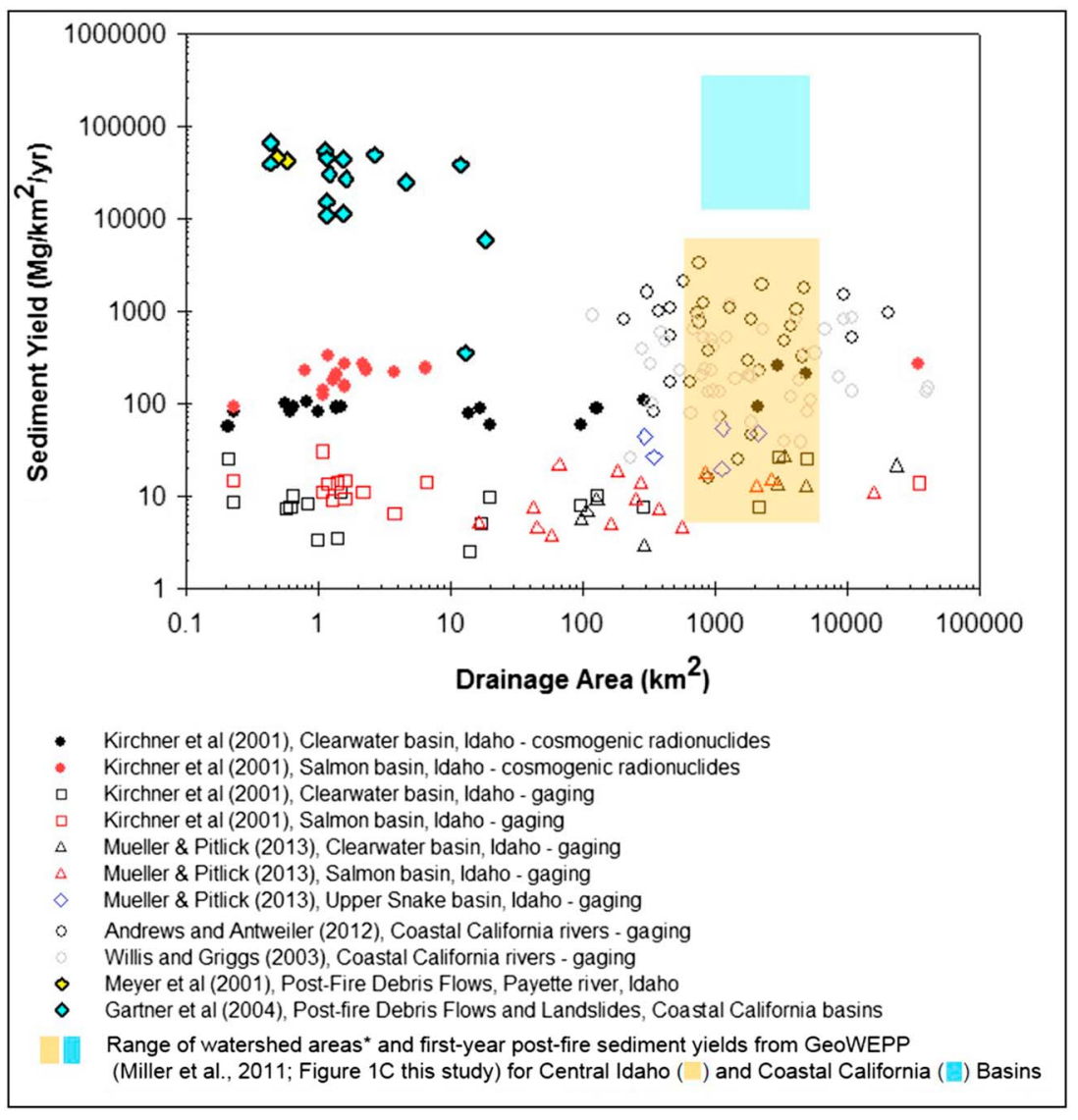

Figure 3. Comparison of watershed sediment yield estimates for the first year postfire from the GeoWEPP erosion model [Miller et al., 2011] used in this study, with other relevant measured and modeled watershed sediment yields from the published literature. The drainage areas presented for GeoWEPP span the area of the smallest and largest HUC8 watershed in the region.

influenced by periodic wildfires, plot near the middle of the range in GeoWEPP estimates in the Idaho Batholith. GeoWEPP estimates are smaller than sediment yields measured for postfire debris flows [Meyer et al., 2001] for the Idaho Batholith. In contrast, the GeoWEPP estimates appear to be too high in coastal Northern California, because while they are greater than the average annual sediment flux observed at gaging stations [Andrews and Antweiler, 2012; Willis and Griggs, 2003], they are also often greater than or equal to sediment yields measured from postfire debris flows [Gartner et al., 2004].

These comparisons underscore the observation that GeoWEPP tends to overpredict postfire sediment yield in wet environments (e.g., coastal Northern California), as previously reported by Miller et al. [2011]. On the other hand, for the Idaho Batholith region which spans a climatic range typical of much of the Rocky Mountain region, predictions of postfire sediment yields fall in the expected range between unburned sediment yields from stream gaging and large, but discrete, postfire debris flows. Thus, we conclude that projected increases in postfire sediment yield due to hillslope erosion are statistically significant for many watersheds when accounting for uncertainties associated with the GeoWEPP estimates. Furthermore, runoff-generated hillslope erosion processes may be the dominant sediment supplier for postfire debris flows [Cannon et al., 2001], wherein debris flow surges develop as a result of failure of accumulated hillslope material in low-order channels during runoff events [Kean et al., 2013]. The hillslope erosion estimates from the GeoWEPP model may therefore (inadvertently) capture a significant component of the sediment volume measured in debris flow deposits and estimated from empirical relations in some environments [e.g., Gartner et al., 2008]. A fully coupled model that maintains sediment continuity across hillslope and debris flow process domains, and, ultimately, routes sediment through channel networks is needed to accurately predict post-fire erosion and sedimentation across a wide range in watershed scale. Future efforts to improve projections of 
postfire sediment yield should therefore address issues related to the accuracy of postfire hillslope soil erosion models such as GeoWEPP, coupling models that bridge the differing spatiotemporal ranges of all postfire geomorphic processes that contribute sediment to channel networks, and downstream sediment routing and the validation of modeled postfire sediment yields at very large watershed scales.

\section{Conclusion}

We project that nearly nine tenths of watersheds in the western USA will undergo $>10 \%$ increases in sedimentation between 2001 and 2050 due to increases in burning and postfire hillslope soil erosion. Approximately one third will undergo $>100 \%$ increases. The projected increases are significant for 388 of 471 watersheds analyzed, and we identify 37 watersheds for which the increases are especially robust and certain with respect to the range of natural variability in climate, fire, and erosion. Many growing cities and towns in the region rely on water from rivers and reservoirs that originates in watersheds where sedimentation is projected to increase [Weidner and Todd, 2011; Brown et al., 2008]. Increased sedimentation will negatively impact water supply for some of these communities by reducing reservoir storage, by increasing the need and cost for reservoir maintenance, or by increasing the cost to treat and deliver water to people [Smith et al., 2011; Palmieri et al., 2001]. Water quality will be negatively impacted for some of these communities either by the increase in sediment in water itself [Murphy et al., 2015] or by increases in nutrients and pollutants adsorbed to sediment [Smith et al., 2011].

\section{Acknowledgments}

The project described in this publication was supported by a grant from the Department of the Interior Northwest Climate Science Center (NW CSC), the U.S. Geological Survey's Ecosystems Mission Area, the U.S. Geological Survey's Land Change Science Program and the U.S. Geological Survey's National Assessment of Ecosystem Carbon Sequestration and Greenhouse Gas Fluxes. This manuscript is submitted for publication with the understanding that the United States Government is authorized to reproduce and distribute reprints for Governmental purposes. Any use of trade, product, or firm names is for descriptive purposes only and does not imply endorsement by the U.S. government. At the time of manuscript publication, the data for this study will be published and made freely available online by the USGS (https://doi.org/ 10.5066/F7BV7DS8).

\section{References}

Andrews, E. D., and R. C. Antweiler (2012), Sediment fluxes from California coastal rivers: The influences of climate, geology, and topography, J. Geol., 120(4), 349-366, doi:10.1086/665733.

Barbero, R., et al. (2015), Climate change presents increased potential for very large fires in the contiguous United States, Int. J. Wildland Fire, 24, 892-899.

Brown, T. C., M. T. Hobbins, and J. A. Ramirez (2008), Spatial distribution of water supply in the coterminous United States, J. Am. Water Resour. Assoc., 44, 1474-1487, doi:10.1111/j.1752-1688.2008.00252.x.

Cannon, S. H., R. M. Kirkham, and M. Parise (2001), Wildfire-related debris-flow initiation processes, Storm King Mountain, Colorado, Geomorphology, 39, 171-188.

Clayton, J. L., and W. F. Megahan (1986), Erosional and chemical denudation rates in the southwestern Idaho Batholith, Earth Surf. Processes Landforms, 11(4), 389-400.

Dennison, P. E., S. C. Brewer, J. D. Arnold, and M. A. Moritz (2014), Large wildfire trends in the western United States, 1984-2011, Geophys. Res. Lett., 41, 2928-2933, doi:10.1002/2014GL059576.

Eidenshink, J., B. Schwind, K. Brewer, Z. L. Zhu, B. Quayle, and S. A. Howard (2007), A project for monitoring trends in burn severity, Fire Ecol., 3 , 3-21.

Elliot, W., I. Miller, and B. Glaza (2006), Using WEPP technology to predict erosion and runoff following wildfire, ASABE Annual International Meeting, Portland, Oreg.

Finney, M. A. (2002), Fire growth using minimum travel time methods, Can. J. For. Res. Rev. Can. Rech. For., 32, $1420-1424$.

Flanagan, D. C., and M. A. Nearing (1995), USDA-Water erosion prediction project: Hillslope profile and watershed model documentation, USDA-ARS Natl. Soil Erosion Res. Lab., NSERL rep. 10. [Available at https://www.ars.usda.gov/midwest-area/west-lafayette-in/national-soilerosion-research/docs/wepp/wepp-model-documentation/.]

Flanagan, D. C., J. R. Frankenberger, T. A. Cochrane, C. S. Renschler, and W. J. Elliot (2013), Geospatial application of the water erosion prediction project (WEPP) model, Trans. ASABE, 56(2), 591-601.

Flato, G. M., and G. J. Boer (2001), Warming asymmetry in climate change simulations, Geophys. Res. Lett., 28, 195-198, doi:10.1029/ 2000GL012121.

Gabet, E. J. (2003), Sediment transport by dry ravel. J. Geophys. Res., 108(B1), 2049, doi:10.1029/2001JB001686.

Gabet, E. J., and T. A Dunne (2003), Stochastic sediment delivery model for a steep Mediterranean landscape, Water Resour. Res., 39(9), 1237, doi:10.1029/2003WR002341.

Gartner, J. E., E. R. Bigio, and S. H. Cannon (2004). Compilation of post wildfire runoff-event data from the western United States, U.S. Geol. Surv. Open File Rep., 2004-1085. [Available at http://pubs.usgs.gov/of/2004/1085/ofr-04-1085.html.]

Gartner, J. E., S. H. Cannon, P. M. Santi, and V. G. Dewolfe (2008), Empirical models to predict the volumes of debris flows generated by recently burned basins in the western US, Geomorphology, 96(3), 339-354.

Gedalof, Z., D. L. Peterson, and N. J. Mantua (2005), Atmospheric, climatic, and ecological controls on extreme wildfire years in the northwestern United States, Ecol. Appl., 15, 154-174.

Gordon, C., C. Cooper, C. A. Senior, H. Banks, J. M. Gregory, T. C. Johns, J. F. B. Mitchell, and R. A. Wood (2000), The simulation of SST, sea ice extents and ocean heat transports in a version of the Hadley Centre coupled model without flux adjustments, Clim. Dyn., 16, 147-168.

Hawbaker, T. J., and Z. Zhu (2012a), Projected future wildland fires and emissions for the Western United States, in Baseline and Projected Future Carbon Storage and Greenhouse-Gas Fluxes in Ecosystems of the Western United States, edited by Z. Zhiliang and B. C. Reed, U.S. Geol. Surv. Prof. Pap., 1797, chap. 8, 12 pp. [Available at https://pubs.usgs.gov/pp/1797/.]

Hawbaker, T. J., and Z. Zhu (2012b), Baseline wildland fires and emissions for the Western United States, in Baseline and Projected Future Carbon Storage and Greenhouse-Gas Fluxes in Ecosystems of the Western United States, edited by Z. Zhiliang and B. C. Reed, U.S. Geol. Surv. Prof. Pap., 1797, chap. 3, 10 pp. [Available at https://pubs.usgs.gov/pp/1797/.]

Istanbulluoglu, E., D. G. Tarboton, R. T. Pack, and C. Luce (2002), A probabilistic approach for channel initiation, Water Resour. Res., 38(12), 1325, doi:10.1029/2001WR000782. 
Istanbulluoglu, E., D. G. Tarboton, R. T. Pack, and C. Luce (2003), A sediment transport model for incision of gullies on steep topography, Water Resour. Res., 39(4), 1103, doi:10.1029/2002WR001467.

Istanbulluoglu, E., D. Tarboton, G. Pack, R. T. Pack, and C. H. Luce (2004), Modeling of the interactions between forest vegetation, disturbances, and sediment yields, J. Geophys. Res., 109, F01009, doi:10.1029/2003JF000041.

K-1 Model Developers (2004), K-1 Coupled Model (MIROC) Description: K-1 Technical Report 1, edited by H. Hasumi and S. Emori, p. 34, Tokyo, Japan, Univ. of Tokyo, Center for Climate System Research. [Available at http://ccsr.aori.u-tokyo.ac.jp/ hasumi/miroc_description.pdf.]

Kean, J. W., S. W. McCoy, G. E. Tucker, D. M. Staley, and J. A. Coe (2013), Runoff-generated debris flows: Observations and modeling of surge initiation, magnitude, and frequency, J. Geophys. Res. Earth Surf., 118, 2190-2207, doi:10.1002/jgrf.20148.

Kirchner, J. W., R. C. Finkel, C. S. Riebe, D. E. Granger, J. L. Clayton, J. G. King, and W. F. Megahan (2001), Mountain erosion over 10 yr, 10 k.y., and 10 m.y. time scales, Geology, 29, 591-594.

Laflen, J. M., W. J. Elliot, D. C. Flanagan, C. R. Meyer, and M. A. Nearing (1997), WEPP-predicting water erosion using a process-based model, J. Soil Water Conserv., 52(2), 96-102.

Lancaster, S. T., S. K. Hayes, and G. E. Grant (2003), Effects of wood on debris flow runout in small mountain watersheds, Water Resour. Res., 39(6), 1168, doi:10.1029/2001WR001227.

Larsen, I. J., and L. H. MacDonald (2007), Predicting post-fire sediment yields at the hillslope scale: Testing RUSLE and disturbed WEPP, Water Resour. Res., 43, W11412, doi:10.1029/2006WR005560.

Litschert, S. E., D. M. Theobald, and T. C. Brown (2014), Effects of climate change and wildfire on soil loss in the southern Rockies ecoregion, Catena, 118, 206-219.

Littell, J. S., D. McKenzie, D. L. Peterson, and A. L. Westerling (2009), Climate and wildfire area burned in western U. S. ecoprovinces, 1916-2003, Ecol. Appl., 19, 1003-1021.

MacDonald, G. M. (2010), Water, climate change, and sustainability in the southwest, Proc. Natl. Acad. Sci. U.S.A., 107, 21,256-21,262.

Maurer, E. P., L. Brekke, T. Pruitt, and P. B. Duffy (2007), Fine-resolution climate projections enhance regional climate change impact studies, Eos Trans. AGU, 88, 504-504.

Meyer, G. A., J. L. Pierce, S. H. Wood, and A. T. Jull (2001), Fire, storms, and erosional events in the Idaho Batholith, Hydrol. Processes, 15(15), 3025-3038.

Meyer, G. A., and J. L. Pierce (2003), Climatic controls on fire-induced sediment pulses in Yellowstone National Park and central Idaho: A long-term perspective, For. Ecol. Manage., 178, 89-104.

Miller, M. E., L. H. MacDonald, P. R. Robichaud, and W. J. Elliot (2011), Predicting post-fire hillslope erosion in forest lands of the western United States, Int. J. Wildland Fire, 20, 982-999.

Moody, J. A., and D. A. Martin (2001), Initial hydrologic and geomorphic response following a wildfire in the Colorado front range, Earth Surf. Processes Landforms, 26(10), 1049-1070.

Moody, J. A., and D. A. Martin (2009), Synthesis of sediment yields after wildland fire in different rainfall regimes in the western United States, Int. J. Wildland Fire, 18, 96-115.

Mueller, E. R., and J. Pitlick (2013), Sediment supply and channel morphology in mountain river systems: 1. Relative importance of lithology, topography, and climate, J. Geophys. Res. Earth Surf., 118, 2325-2342, doi:10.1002/2013JF002843.

Mueller, E. R., M. E. Smith, and J. Pitlick (2016), Lithology-controlled evolution of stream bed sediment and basin-scale sediment yields in adjacent mountain watersheds, Idaho, USA, Earth Surf. Processes Landforms, 41, 1869-1883, doi:10.1002/esp.3955.

Murphy, S. F., R. B. McCleskey, and D. A. Martin (2015), The role of precipitation type, intensity, and spatial distribution in source water quality after wildfire, Environ. Res. Lett., 10, 1-13.

Nicks, A. D., L. J. Lane, and G. A. Gander (1995), Weather generator. USDA-water erosion prediction project hillslope profile and watershed model documentation. NSERL rep., (10), 2-1.

Omernik, J. M., and G. E. Griffith (2014), Ecoregions of the conterminous United States: Evolution of a hierarchical spatial framework, Environ. Manage., 54, 1249-1266.

Palmieri, A., F. Shah, and A. Dinar (2001), Economics of reservoir sedimentation and sustainable management of dams, J. Environ. Manage., 61, 149-163.

Pelletier, J. D., A. Brad Murray, J. L. Pierce, P. R. Bierman, D. D. Breshears, B. T. Crosby, M. Ellis, E. Foufoula-Georgiou, A. M. Heimsath, and C. Houser (2015), Forecasting the response of Earth's surface to future climatic and land use changes: A review of methods and research needs, Earth's Future, 3(7), 220-251.

Pierce, J. L., G. A. Meyer, and A. T. Jull (2004), Fire-induced erosion and millennial-scale climate change in northern ponderosa pine forests, Nature, 432, 87-90.

Renschler, C. S., D. C. Flanagan, B. A. Engel, and J. R. Frankenberger (2002), GeoWEPP-the geo-spatial interface for the Water Erosion Prediction Project, in 2002 ASAE Annual Meeting, p. 1, American Society of Agricultural and Biological Engineers.

Robinne, F.-N., et al. (2016), A global index for mapping the exposure of water resources to wildfire, Forests, 7(1), 22.

Rogelj, J., M. Meinshausen, and R. Knutti (2012), Global warming under old and new scenarios using IPCC climate sensitivity range estimates, Nat. Clim. Change, 2, 248-253.

Sankey, J. B., et al. (2015), Predicting watershed post-fire sediment yield with the InVEST sediment retention model: Accuracy and uncertainties. SEDHYD 2015, Joint 10th Federal Interagency Sedimentation Conference and 5th Federal Interagency Hydrologic Modeling Conference, Reno, Nev. [Available at http://www.sedhyd.org/2015/openconf/modules/request.php?module=oc_program\&action=summary.php\&id=170.]

Shakesby, R. A., and S. H. Doerr (2006), Wildfire as a hydrological and geomorphological agent, Earth Sci. Rev., 74, 269-307.

Smith, H. G., G. J. Sheridan, P. N. Lane, P. Nyman, and S. Haydon (2011), Wildfire effects on water quality in forest catchments: A review with implications for water supply, J. Hydrol., 396, 170-192.

Stephens, L., et al. (2014), Temperate and boreal forest mega-fires: Characteristics and challenges, Front. Ecol. Environ., 12, 115-122.

Weidner, E., and A. Todd (2011), From the forest to the faucet: Drinking water and forests in the US. Methods paper, ecosystem services and markets program area, State and Private Forestry. USDA Forest Service. [Available at http://www.fs.fed.us/ecosystemservices/pdf/forests2faucets/F2F_Methods_Final.pdf.]

Westerling, A. L., H. G. Hidalgo, D. R. Cayan, and T. W. Swetnam (2006), Warming and earlier spring increase western US forest wildfire activity, Science, 313, 940-943.

Willis, C. M., and G. B. Griggs (2003), Reductions in fluvial sediment discharge by coastal dams in California and implications for beach sustainability, J. Geol., 111(2), 167-182, doi:10.1086/345922. 